The Distribution of Human and Animal Life in Western Arctic America Author(s): Viljalmur Stefansson

Source: The Geographical Journal, Vol. 41, No. 5 (May, 1913), pp. 449-459

Published by: geographicalj

Stable URL: http://www.jstor.org/stable/1778162

Accessed: 21-06-2016 00:15 UTC

Your use of the JSTOR archive indicates your acceptance of the Terms \& Conditions of Use, available at

http://about.jstor.org/terms

JSTOR is a not-for-profit service that helps scholars, researchers, and students discover, use, and build upon a wide range of content in a trusted digital archive. We use information technology and tools to increase productivity and facilitate new forms of scholarship. For more information about JSTOR, please contact support@jstor.org.

The Royal Geographical Society (with the Institute of British Geographers), Wiley are collaborating with JSTOR to digitize, preserve and extend access to The Geographical Journal 


\section{THE DISTRIBUTION OF HUMAN AND ANIMAL LIFE IN WESTERN ARCTIC AMERICA.*}

\section{By VILJALMUR STEFANSSON.}

'T'He northern portion of Alaska is a low triangular coastal plain. The south side or base of this triangle is formed by that section of the Rocky mountains which stretches approximately true east and west from where they meet the ocean at Cape Lisburne, just north of Behring straits to where they approach again within 10 or 15 miles of the coast at the international boundary line in the east. This plain is entirely devoid of spruce or other forest growth, although several of the larger rivers are well supplied with wood for fuel through the abundance in their bottom lands of willow and alder, which sometimes grow to as much as 25 feet in height and 6 inches in diameter. This entire plain was, until fifty years ago, occupied by a fairly dense Eskimo population-dense as compared with other Eskimo districts. While the people who lived on the coast did not use the abundant driftwood for fuel in winter, but depended entirely upon oil lamps, these islanders built dome-shaped houses of willow and moss and heated them with open fires built on the middle of the floor underneath a square opening in the roof, which serred both for a window and a chimney. Because they used wood for fuel these people were in winter chiefly confined to the river valleys, while they wandered at will over the entire plain in summer, using moss and such things for firewood, and especially the Andromeda tetragona. One of the groups, however, the Oturkagmiut, who lived between the headwaters of the Colville and Icy cape, depended even in winter on the Andromeda chiefly for fuel.

Some of the rivers and lakes yielded the people a food supply in fish and in rabbits and ptarmigan which frequented the bushes around them and could be snared. But the main reliance was always caribou, which until ten or twelve years ago were found everywhere in vast numbers. It has until recently been a matter of dispute among zoologists whether or not the musk ox also was a recent animal in this district, and the weight of opinion seemed to be against its having been found there in recent times, although such well-known authorities as Sir John Richardson said offhand that they were numerous west of the Mackenzie river. It is a matter of common knowledge, however, among the Eskimo of Point Barrow that musk oxen were killed inland frequently by their ancestors and that the last one was killed 30 or 40 miles south of Point Barrow three or four years after Maguire wintered there in the Plover. In other words it must have been about 1860 , or a year or two before, that the last musk oxen were killed. Our archæological investigations on the north coast of

* Royal Geographical Society, March 10, 1913. Map, p. 516. 
Alaska have yielded strong confirmatory evidence of the native stories, for not only are the bones of the musk oxen found in great numbers in the kitchen middens or refuse heaps around the villages (and we feel sure these cannot well be over five hundred or six hundred years old at the most), but we even found two musk ox skins in a fair state of preservation buried in houses which it seems reasonable to suppose were not deserted over a hundred years ago.

It is the nature of the musk ox that it cannot long survive in any country inhabited by a hunting people. We find nowadays that the range of the musk ox and the range of the Eskimo are mutually exclusive, for the Eskimo always exterminate those within their range. Their hunting method allows of nothing else, for when a dog or two have been set on a band of musk oxen they will hold the animals in one place indefinitely and give the Eskimo time to kill them at leisure.

Strange as it may seem, we found archæological evidence at Point Barrow to show that moose were now and then killed there, although this is at least 200 miles from the timber line proper, and although the moose is correctly enough considered an animal of the forest. It has happened occasionally, too, in recent years, that moose have been killed within 20 miles of Point Barrow, as well as lynx and wolverines, which are likewise forest animals.

While the caribou furnished 70 or 80 per cent. of the entire foodsupply of the inland Eskimo, they were far less important in the economy of the coast tribes, which needed caribou chiefly for clothing, although, of course, they delighted in the eating of venison, which everywhere among Eskimo is the preferred among all foods. The most important food animal at Point Barrow was always the bow-head whale, and remains so even today. The walrus which are abundant to the south at Point Hope and even at Icy Cape come but rarely to Point Barrow, and are of secondary importance. The seal was no doubt always next to the whale in importance. 'They were hunted at all seasons, but especially in winter, when they were taken in nets. Of course, this cannot apply to the ancient Eskimo, for our investigations have shown that the knowledge of nets and netting is but a recent thing on the coast of Alaska, although it no doubt antedates the coming of white men by a century or two.

In the spring and summer ducks and geese, especially the former, are an important item of diet. They are pursued in kayaks when moulting, and killed with clubs, and large numbers of them are also secured by bolas throwing, for the migration route of the ducks along the coast is so definitely known that a man can stand in one place all day and rely on it that three out of every four flocks will fly within throwing distance. So thickly do the birds come that nowadays a competent man with a shot-gun has been known to secure as many as six hundred ducks in a day.

Fish were apparently always of even less importance to the coastal people than to the inlanders. No sort of shellfish seems ever to have 
been used as food by the liskimo, north of the mouth of the Yukon river at least, although clams and shrimp abound in certain places, and their use is just now being introduced by white men. Berries and roots, which form a considerable item of diet in Katzebue sound and farther south among the Eskimo, are used only to a negligible extent by the people of the north coast.

There are few better examples of the deceptiveness of figures than can be found in the census returns of the United States for Northern Alaska, by which it is possible to prove to the satisfaction of any one who does not know the conditions, that the Eskimo population of the country has remained approximately constant for the last thirty years, whereas the fact probably is that there are less than ten persons now for every hundred who lived north of the mountains in 1860. The explanation is found in the circumstance that the census has concerned itself only with the population of the coast. During the last half-century-or since the beginning of the introduction of firearms-the caribou bave been becoming fewer and fewer, and the conditions of life consequently harder and harder, while on the coast the conditions of life were simultaneously becoming easier through the growth of the whaling industry and the prodigality with which food and gear were given by white men to those who engaged in whaling in their employ. While the death-rate on the coast has been increasing year by year, and while the graves have multiplied constantly on every hilltop, there have continually moved in from the interior families and groups of families to supply the vacant places. In 1884, when Mr. Brower (who still bas a whaling station at Point Barrow) came there first he found a population of about four hundred in the village of Cape Smythe. 'The population of Cape Smythe is about four hundred to-day - with this fundamental difference, however, that whereas at least three hundred of the four hundred of thirty years ago were people born in the village and recognized as belonging to that tribe through both parents, there now are in it only three (instead of three bundred) people who belong to the Cape smythe tribe and twenty or twenty-one who are descended from it through one parent. There are perhaps half a dozen members of the Cape Smythe tribe living in other places than Cape smythe. In other words, while the village has remained stationary in numbers, and is shown to be so by the United States census returns, the Cape Smythe tribe has been practically exterminated. Those who live there now are immigrants and a conglomeration of dozens of tribes whose parentage is from as far south-west as St. Lawrence island and as far east as the Mackenzie river. Most of them, however, are descendants of inlanders. Apparently the inlanders can withstand the ravages of civilization more easily than can the coast people. Although they also have paid their toll both in lives and in the health of those who have not actually died as yet, still it seems clear that the mixture of Athabascan Indian blood (which is evident in their physiognomy and well known to us through the history of inter-marriages) has 
been made better able to withstand the contagious diseases introduced by white men than are the more nearly pure-blooded Eskimo of the coast.

Among the Mackenzie Eskimo whaling was carried on also, although not by people of the delta proper, but only by those on its outlying flanks, towards Herschel island on the west and Cape Bathurst on the east. The walrus does not reach them except that a single individual or two may be seen once in a decade, so seldom indeed that they are feared greatly by the Mackenzie Eskimo and considered supernatural. The white whale (belugu) is of considerable importance in certain places, especially on the eastern margin of the delta. Sealing was practised by the same villages that engaged in whaling, but not in the delta proper. Dependence was had on the caribou for clothing everywhere, but as an article of food supply they were no more important here than at Point Barrow. Fish, however, played a much more important rôle than anywhere to the west, especially after the introduction of fish nets, which occurred about one hundred and twenty-five years ago. So far as one can learn, moose have been found in the delta "always," and musk oxen were killed just east of the delta within the memory of living men, while back of Cape Parry, just a little east of the eastern limit of the Mackenzie Eskimo proper, they were killed as late as ten years ago, and there is little doubt that a few miles farther east still some of them survive to-day.

Although we have nothing approaching an exact census of the Mackenzie Eskimo of half a century ago, we can make a more approximately correct estimate than is possible farther west. Richardson tells us that in 1848, when he passed the white-whale-hunting village of Kittigaryuit two hundred kayaks came out and surrounded his boat. From this we can form a fairly clear idea of the population of that one village, for we know that kayaks during the white-whale hunt are used only by able hunters. In other words there were no old men, no boys and no women among the two hundred whom Richardson saw. Each man in a boat must have represented at least three ashore, or more probably four, which gives us a minimum population for that village alone of eight hundred and a maximum of a thousand or eleven hundred. This was the largest single village in the district always, but it was only one of dozens and several of the others, such as, for instance, the ones at Point Atkinson and Cape Bathurst, must have been at least half as large. There were also people on the Eskimo Lakes and elsewhere inland who did not come to the sea-coast for the white whale hunt, for the whale-hunting season coincides in part with the caribou hunting season. There were also the big whaling villages west of the delta at Shingle point, King point, and Kay point, and three on Herschel island, all of which belonged to the Mackenzie district. Four thousand seems an unreasonably low estimate, therefore, for the population of the delta. Let us divide this already low estimate by two and we have a population of two thousand, which is evidently far below the real number. But supposing there were only two thousand in 1848, we have before us 


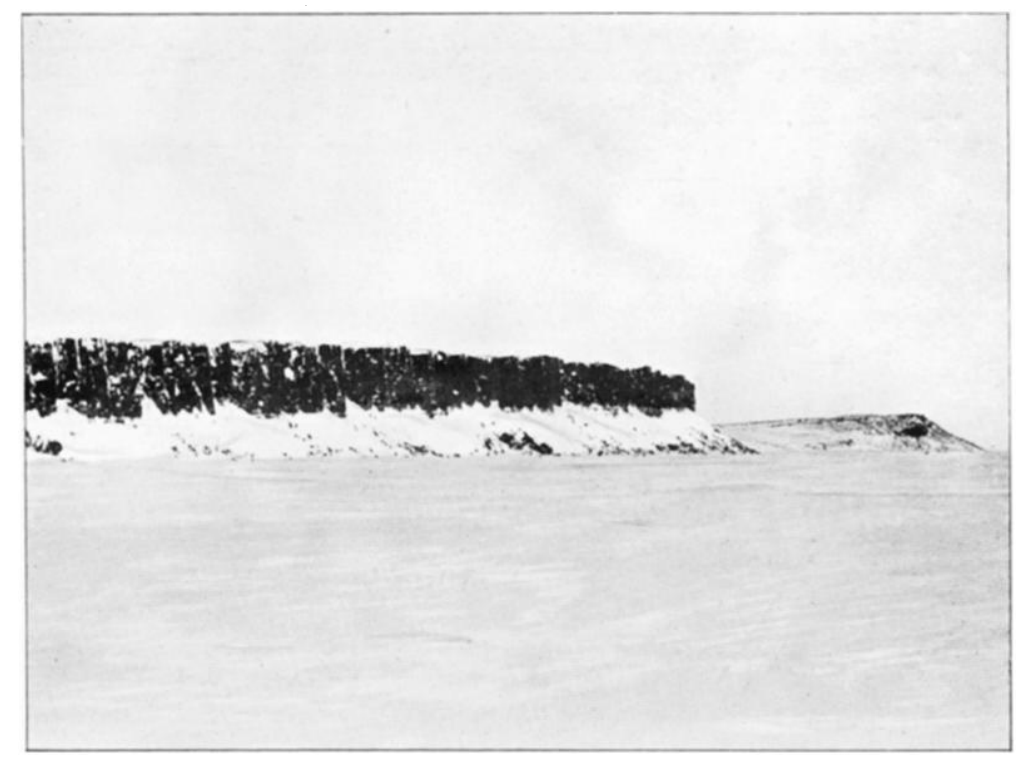

CORONATION GULF ISLANDS SEEN FROM SOUTH-WEST-THE NEARER $\frac{1}{4}$, THE MORE DISTANT $\frac{3}{4}$, MILE AWAY.

Most of the islands in western Coronation gulf have a precipice to south-east, and about a $15^{\circ}$ or $20^{\circ}$ slope to north-west into the sea, with reefs running off to north-west and deep water close to south-east ends.

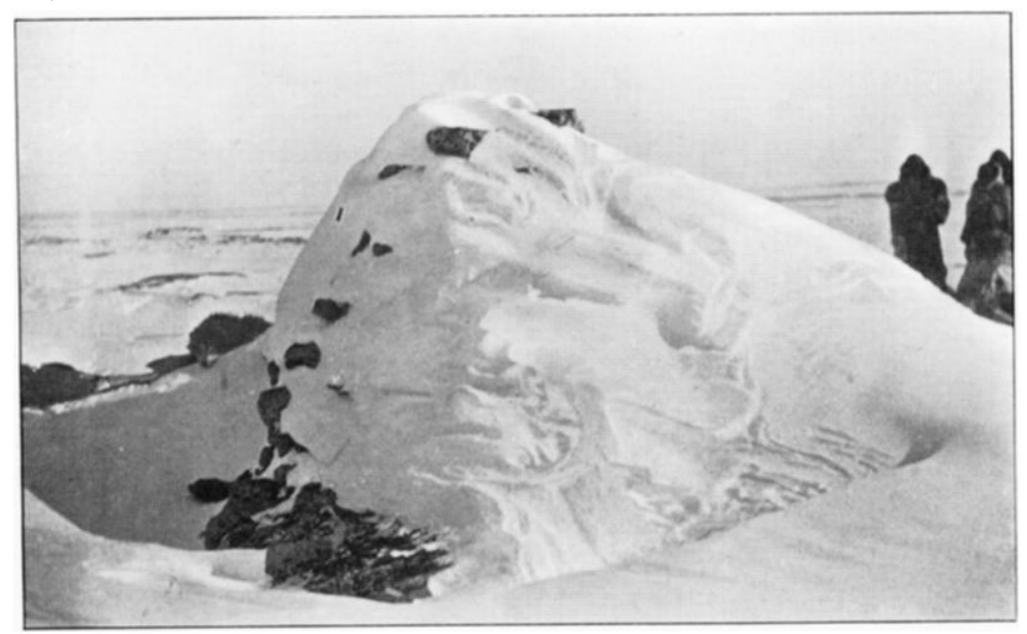

ANCIENT CONICAL STONE HOUSE, SIMPSON BAY, VICTORIA ISLAND.

The present inhabitants make no permanent dwellings of any kind, and do not know who built these stone ones. They are feared, and never entered. 


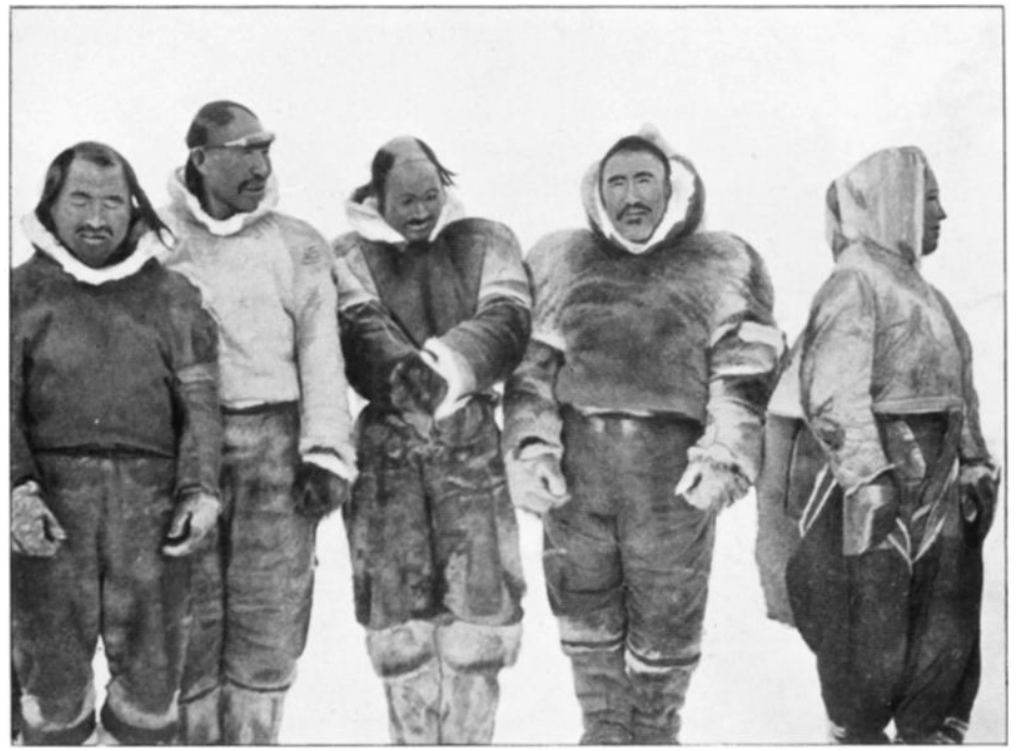

ESKIMO NEN AND ONE WOMAN.

All of those shown in this picture have light eyebrows, and the beards of those who wear any range from dark brown to light brown tinged with red. Prince Albert sound, Victoria island.

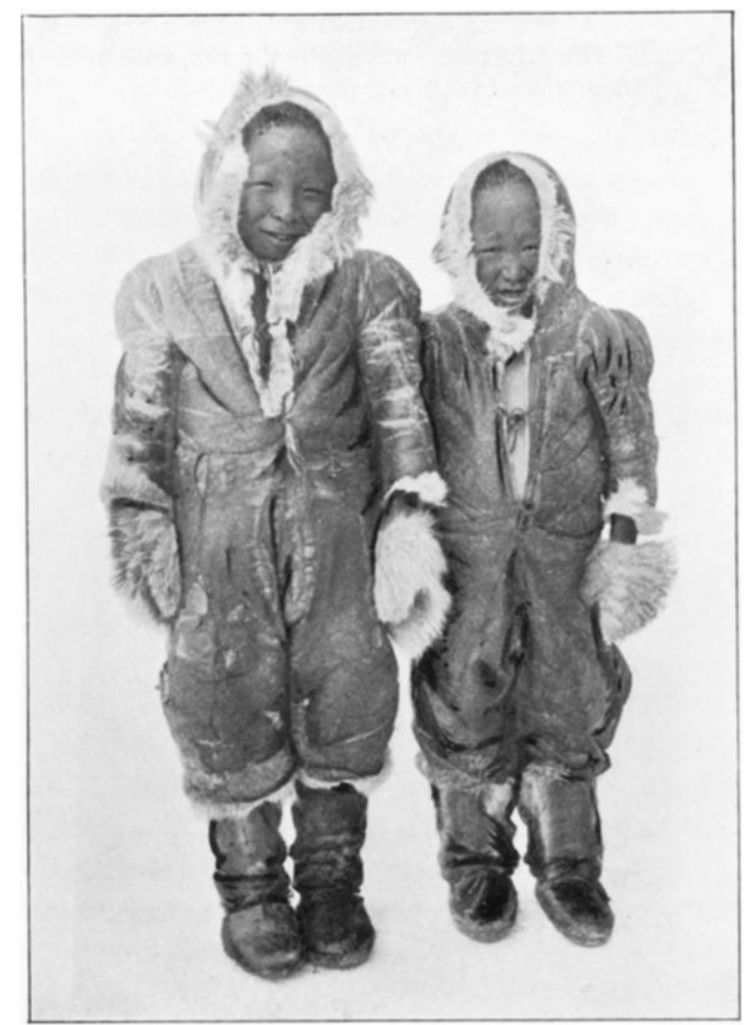

TWO BOYS OF SOUTH-WEST VICTORIA ISLAND, AGE ABOUT SIX AND EIGHT YEARS. 
the startling fact that the present population is less than three per cent. of that of sixty years ago, for the Mounted Police census of two years ago showed only forty descendants of the local people, although there were also in the country considerably over a hundred immigrants; and since this census of two years ago six of the forty have died and three have gone permanently insane. This is a striking picture of the effects of civilization on the Eskimo, striking especially when we compare it, as we shall presently do, with that of the fortunes of other Eskimo, who during the same sixty years have been mercifully free from civilized contact.

We know from traditions both in the east and west that the present area of isolation, stretching 300 miles from Cape Bathurst to Cape Bexler, did not exist a hundred years ago. There are traditions of commercial intercourse on both sides, and we find all over Alaska and the Mackenzie district steatite cooking utensils and oil lamps made of stone from the quarries east of the Coppermine river. There is also a considerable series of ruined village sites along the entire coast, the greater part of which shows us that the whaling industry did not stop with Cape Lyon, as Dr. Richardson thought, but was carried on at least as far east as Crocker river.

Although we ourselves saw less than a thousand individuals east of Cape Bexley and in Victoria island, we can safely say that there is a total population of considerably over two thousand between Cape Bexley and those Eskimo with whom Amundsen came in contact during his stay in King William island. Some of these tribes were visited by the early English explorers, but most of them were not. Unfortunately, none of the explorers give us a census of the people they saw. One has, therefore, to read between the lines in Collinson and M'Clure's books to get the idea that there may have been about two hundred individuals in the early fifties in the Prince Albert sound group with which both came in contact. We found there two hundred and twenty in May, 1910. In other words, so far as we can judge, they have held their own for sixty years, or gained a little; and these are the same sixty years during which the Mackenzie Lskimo have been civilized, Christianized, and reduced by white men's diseases from over two thousand to less than forty.

These statements are based on records which may be considered, though hardly with a show of justice, to have been misinterpreted, but one does not have to go to any records to get the present contrast in health and prosperity. In 1911 there were at Cape Bathurst about forty civilized Eskimo, partly Mackenzie river people and partly immigrants, and out of that forty a good twenty were seriously ill, two of them permanently insane, while in this uncivilized group (which from the very beginning has been isolated from white men except for the very slight contact with Collinson and $\mathbf{M}^{\circ} \mathrm{Clure}$ ), we found only one sick person in over two hundred (instead of twenty out of forty), not counting as sick an old man who had been blind for something like eight years. And not only were many of the civilized Mackenzie

$$
\text { No. V.-MAY, 1913.] }
$$


people chronically ill, tut they are also insufficiently clothed and insufficiently fed. There was in 1911 probably not a single individaal in the Prince Albert sound group who did not have at least two complete suits of warm skin clothing and many had several suits, while among the civilized Eskimo of the Mackenzie at any time between 1908 and 1912 a man who had even one good suit was hard to find. Most of them are so poorly clad that they are unable to hunt seal in winter through being insufficiently protected from the cold. This insufficiency of clothing is the result of two things: first, the introduction of rifles has destroyed the caribou apon which they depended for clothing, and secondly the multiplication of new wants, such as the desire for tea, tobacco, sugar, and ammunition, forces them to barter for these expensive luxuries the skins which they might otherwise have used to dress in for the cold.

The food supply of the Eastern or Copper Eskimo differs from that of the loint Barrow people in the absence of the bowhead whale and walrus, and from that of the Mackenzie rivor people in the absence of moose and white whale and the comparatively insignificant rôle played by river and sca fish. There are, true enough, plenty of fish in the waters of most of the Eastern Eskimo districts, but through the lack of fish nets they are unable to secure many, although one tribe, that of Albert Edward bay on the east coast of Victoria island, do live on fish to a considerable extent. In general it may be said that the people live on seals for nine months in the year and on caribou for three months. The most westerly tribe, that of Prince Albert sound, do not winter on the sound whose name we give them, but as a matter of fact, on the south-east coast of Banks island, where they live on a diet differing from that of any other Eskimo tribe known to us; for more than three-fourths of their food consists of polar bears, which they hunt with dogs, knives, and bows and arrows on the ice off Nelson head, where the strong currents keep the lanes of water open all winter. Those who live farther north-east on Banks island in the neighbourhood of De Salis bay do depend upon seal to a considerable extent.

The other people of Victoria island live in winter on the ice of Dolphin and Union straits and Coronation gulf, while those of Albert Edward bay go out into Dease strait. They are the group with whom Hansen and listvedt of Amundsen's Gjoa expedition came in contact the spring of 1905. 'The people of the mainland to the south also occupy Dolphin and Union straits and Coronation gulf in winter.

The winter villages of all these people (except those of Banks island) are built as nearly as possible in the middle of the gulfs and straits, for their sole reliance is the seal. The polar bears, common around Nelson head, are so nearly absent from Coronation gulf that we saw there men who had grown to mature age without ever seeing a live polar bear. The sealhunting method on these stretches of level ice is entirely that of having the dogs smell out the breathing holes of the seals, after which the hunter waits beside the breathing-hole until the seal rises and then harpoons it 
from above. Of course this process is not so simple as it sounds; in fact, it is so complicated that a full description of it can scarcely have a place in the present paper. It is a method, however, well known among all those Eskimo who winter on level ice, where leads of open water are not to be found.

Musk oxen are fairly abundant in Banks island, but they have been exterminated in Victoria island, unless indeed there may be a few on the north coast, which is but seldom visited by the Minto Inlet Eskimo. The caribou of Banks island stay there all the year round, for the food seems suited to them there, but the millions which frequent Victoria island in summer leave for the south so soon as the ice of Dolphin and Union straits and Coronation gulf becomes strong enough to bear their weight in crossing, which usually happens late in October or early in November. The migration of the caribou is not seasonal in the same sense as is the migration of birds. On Coronation gulf, for instance, large numbers of caribou stop when they reach the south shore and remain there all winter, while in Dolphin and Union straits, doubtless because the food conditions are different, the animals keep going until they reach the vicinity of Great bear lake and the Dease river. It was the knowledge of this habit that made us choose the headwaters of the Dease as the site of our winter camp for 1910-1911, where for a year we lived entirely on caribou.

As mentioned above, the range of the musk ox is completely outside the habitual range of the Eskimo. For that reason there are no musk oxen on the mainland in the vicinity of the Coppermine river south as far as Bear lake, although there probably are some west of that district in the tracts unvisited by Eskimo or Indian which stretch west to Harton river and Cape Parry. East of the Coppermine you have to go about 100 miles until you come to where the musk oxen are plenty, and from there on eastward to Back river they are no doubt found in most places. This is ground which Eskimo penetrate occasionally only, and in which the musk ox has a chance of survival.

Contrasting pleasantly with the gradual retreat and approaching extermination of both the caribou and the musk ox is the increase in numbers of three game animals: the musk rat, the beaver, and the moose. Half a century ago, to the westward of Great Bear lake, moose were found only on the west side of the Mackenzie river. They have since crossed the river until something like twenty years ago they reached the west end of Bear lake, some ten years ago they got to the east end of the lake, and three years ago the first moose were seen on the shores of Coronation gulf by the Rae river Eskimo. The history of the spread of the musk rat has been somewhat similar to that of the moose in this district, although it seems to have preceded the moose by a few decades in some places and by a decade or so in others. They are now found in many of the small lakes right down to the coast of Coronation gulf and Dolphin and Union straits, but there are hundreds of Eskimo now living who can remember the time 
when they first saw these animals. Being strange through newness they were considered supernatural, and are so even to-day. Although some tribes are hard put to it to find skins enough for clothing, and although they will use the inferior skin of the marmot, they throw away both the skin and meat of the musk rat and use only the tails, which are employed as charms and talismen. The beaver, too, is spreading towards the sea, although he has not as yet attained so high a northing as the musk rat, and will probably always be confined to the timber country.

We have already considered those animals which are of the greatest importance to man along the northern coast of America from Behring straits to the Coppermine. Some of those of less general importance are of special interest in certain districts. The bush rabbit, or snow-shoe rabbit, is found in considerable numbers only in the district between the Anderson river and the Mackenzie, including the deltas and valleys of both these streams, and they are snared and trapped by the Eskimo. The food importance of the lynx is also confined to the same district, for the lynx feeds chiefly on the rabbit. Both willow and rock ptarmigan are (within the limits of the territory under consideration) found wherever the Eskimo are found, but it is only in the northern interior of Alaska that they are much relied upon as food. In that district they are caught in snares, traps, and nets, as well as shot with the guns that have taken the place of the bow and arrow. Snaring and netting are methods unknown to the Eastern Eskimo, and it is self-evident that they cannot hope to secure any large numbers with bow and arrow.

It is especially in the river deltas that birds' eggs are of importance in summer as an article of diet. The Coppermine district, however, is peculiar in that there are practically no nesting-places of any importance near it.

An animal much feared and seldom killed is the Barren Ground grizzly, which in the form of Ursıs arctos Richardsoni, and of probably several other varieties, is found in all the district we have considered. They are not only rare beasts, but are vicious fighters at close quarters, and much more dangerous than polar bears to men who hunt with spears and bows. They are really numerous in the mountains running east from Langton bay to ('rocker river, which is a district at present uninhabited, and has no doubt been so for the better part of a century at least. We saw in the Coppermine region several men who had killed grizzly bears with bow and arrow, and heard stories of how hunters had been maimed and killed in this dangerous pursuit. One man whom we saw was horribly disfigured through a blow on the head from the paw of a grizzly. It was said that this blow was so nearly fatal that the man had been sick a year from its effects.

An animal which deserves as an article of food supply earlier mention than it gets in this presentation, is the marmot, which is eaten by all tribes familiar to us, except those on the eastern edge of the Mackenzie delta, to whom the animal is taboo. They are trapped in various ways, and snared 


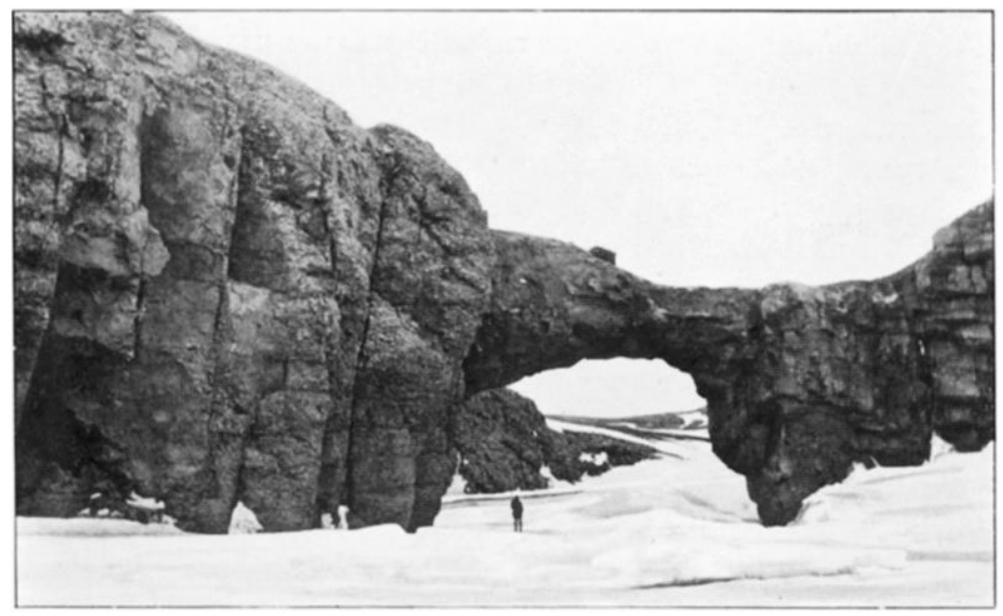

NATURAL BRIDGE NEAR POINT DEASE THOMPSON.

This bridge is figured in Dr. Richardson's 'Arctic Search Expedition.'

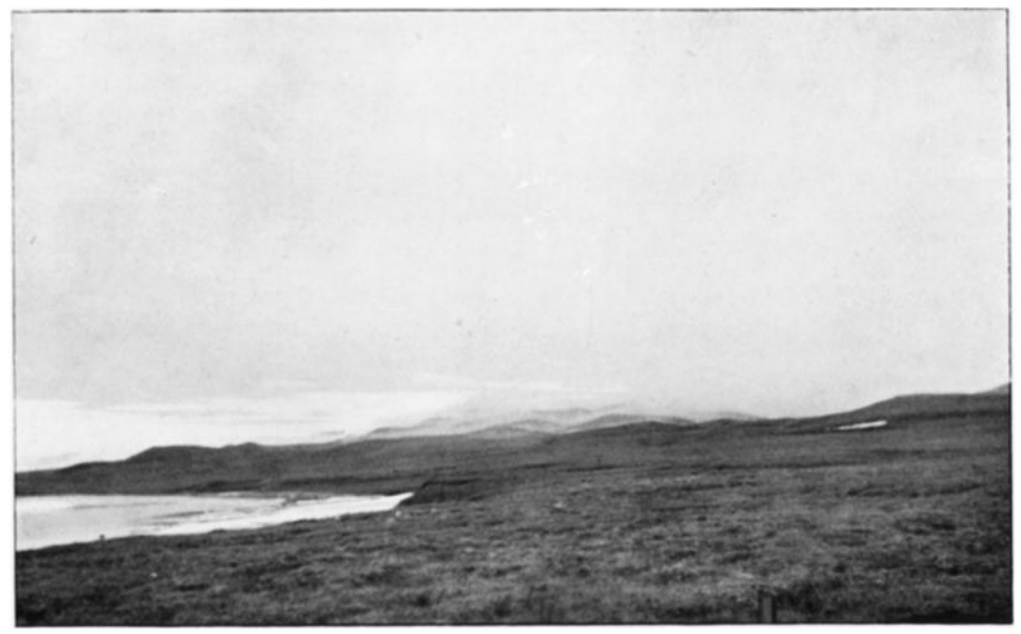

TYPICAL BARREN GROUND, NEAR SOUTH-WESTERN CORNER OF DARNLEY BAY. 


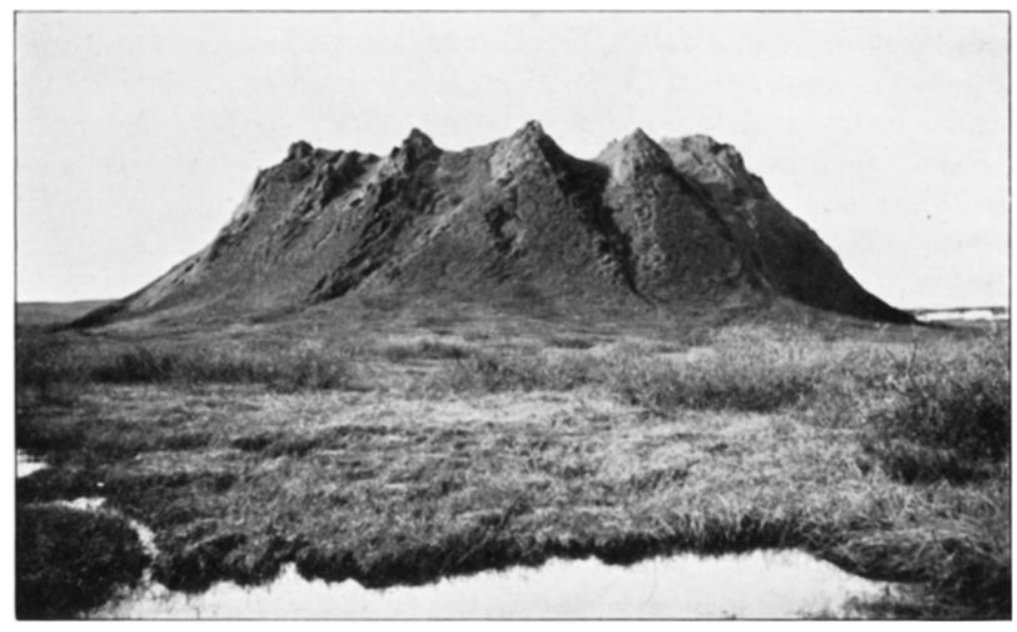

"MUD VOLCANO" C. 150 FEET HIGH, ON LOWLAND AT THE FOOT OF THF PARRY PENINSULA, ABOUT 10 MILFS EAST OF LANGTON PAY.

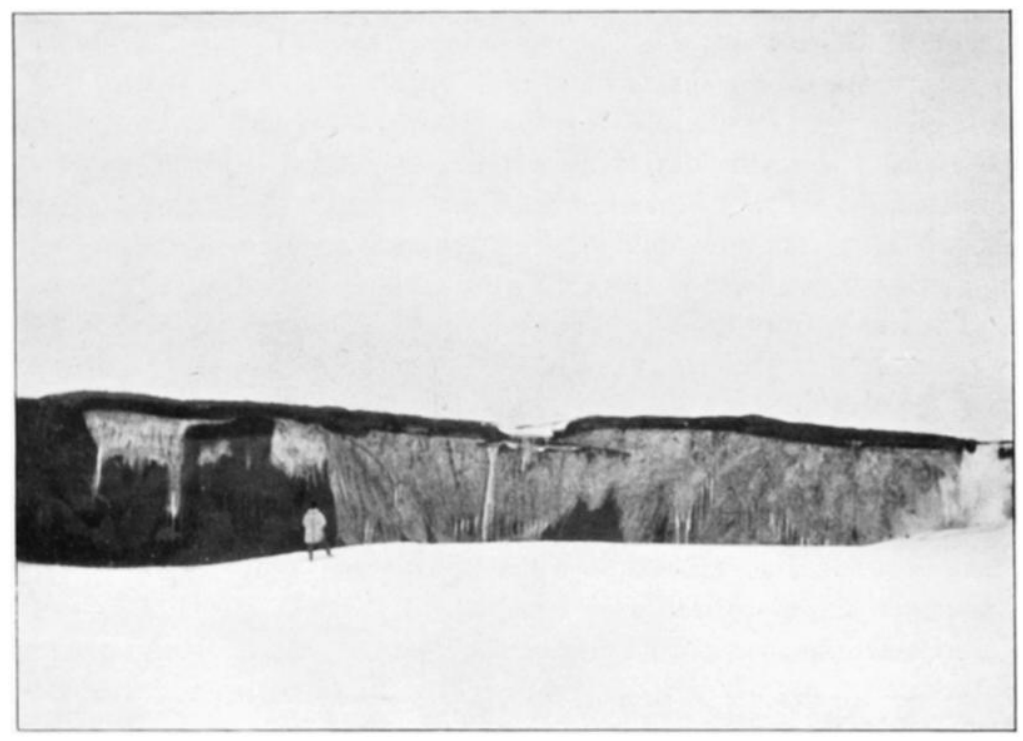

BOULDERS OF ICE IN (ALLUVIAL ?) CUT BANK ON SEA-FRONT NEAR PITT POINT, NORTH COAST OF ALASKA. 
as well as shot by the Alaskan Eskimo, and are both snared and shot by those of Coronation gulf. In saying above that the Copper Eskimo were unfamiliar with the use of snares, the meaning is that they do not use snares that can be set and then left by the hunters. The snaring of the marmot is done chiefly by the women and small boys who put a noose in the mouth of the animal's hole and sit by till the marmot comes out, when they pull the string and usually catch it about the neck.

A curious thing, and possibly of some ethnological significance, is the fact that although various berries abound among the Coronation galf Eskimo, of which the Eskimo further west are fond as an article of food, these are not eaten to any extent by the easterners. The salmon berry, which is both the most abundant and the most palatable of the Copper. mine river berries (in my estimation and that of the western Eskimo), is never tasted by the local people. In our migratory life among them we often had occasion to travel through extensive berry patches at a time when the fruit was ripe, and my Eskimo companions tried to teach their local countrymen to eat the salmon berry, but with very little success so far as the adults were concerned, though a few children readily picked up the habit.

The distribution of human life in the region covered by our investigations was evidently somewhat different in the near past from what it has been during the last fifty years, and especially from what it is to-day. It is a matter of common knowledge among the people of Prince Albert sound and Minto inlet that a large tribe occupied the eastern side of Banks island up to well within the memory of people now living. It was this tribe who discovered M'Clure's ship the Investigator a year or two after she was abandoned in the Bay of Mercy, and they attained some commercial importance locally by becoming the distributors of the iron and other valuable things which they obtained from the ship and abandoned stores, although other tribes, such as the Prince Albert sound one, used after they learnt of the ship from the Banks islanders to make trips to the Bay of Mercy themselves to plunder her on their own account. The Banks island tribe, however, suffered from a series of famines, which eventually ended, something over twenty years ago, in the destruction of the whole tribe. Other people who occupied the west coast of Victoria island north of Minto inlet have similarly disappeared in recent times.

There is still living at Cape Bathurst a woman who was about fourteon years old when she saw Richardson's and Rae's party in 1848. She was born near Langton bay, about 90 miles east of Cape Bathurst, and remembers the time, when a few years before Richardson's coming, her people abandoned Langton bay and went west, while others of their neighbours went east and never returned. It is clear from this story, as well as from the archæological evidence and the information gained from the eastern Eskimo, that there were people living along the entire coast from Cape Bathurst to the Coppermine river at the time of Richardson's first 
visit in 1826, although he saw none of them anywhere between Langton bay and Cape Krusenstern. That he should not have seen any is not strange, for the character of the country and the habits of the people living in it are such that the entire population would be expected to be far inland south of the mountains during the summer season. Besides, it was only seldom that Dr. Richardson went ashore, and people who live in snow houses, as many of these may have done, leave nothing behind them near the sea except inconspicuous caches where they have covered up their small belongings under a heap of stones.

While we have been able to show that the Eskimo have, since time immemorial, been in the habit of occupying in summer all the country from Coronation gulf down to the very shore of the east end of Great Bear lake, including the headwaters of the Dease river, it is also clear from the evidence on the ground as well as from the accounts of the early explorers, that the Indiars occupied in winter the territory in which the Eskimo dwelt in summer all the way down to the northern limit of trees, about 15 miles south of Coronation gulf. In our journey north-westward from the mouth of the Dease river to Franklin bay we found remains of ancient Indian lodges along the whole route, although no Indians frequent those parts at present. Not only are the lodges in the river-bed, which might merely prove occasional journeys taken into a far country, but they are also thick everywhere on the high land wherever trees are to be found, and even beyond the limit of trees on the Barren Ground, showing that the Indians, like the wolverines, made occasional incursions into the territory which the habits of the Eskimo had made their own. Tradition tells us that at the time, over sixty years ago, when the last Eskimo lived in the vicinity of Langton bay they used to have occasionally sight of the Indians to the south, whom they feared and with whom they had no intercourse. There seems always to have been some intercourse, although only semi-friendly, between the two races on the Anderson river, while on the Mackenzie the relations might be considered one of open war in which the Eskimo usually took the offensive, a thing that is best shown by the almost yearly war expeditions which they made up the Mackenzie river as far south as Fort Good Hope, which is 400 miles within the limits of the Indian territory and some 600 miles from the ocean.

It is a strange thing that in spite of the explicit testimony to the contrary of such early observers as Richardson, it seems to be generally assumed that wherever Indians and Eskimo met, the Indians took the offensive and that the Eskimo retreated before them. So far as we know, the ovidence is all the other way. Wherever the two met the Indians were the ones to flee, and it is true even to-day that the Indians of Fort Good Hope who have for a century been under the protection of the Hudson's Bay Company, are still in deadly fear of the Eskimo, whose latest hostile attacks antedate the memory of any man now living. On Great Bear lake it is also true that the complete separation between the two 
races was due more to the timidity of the Indians than to that of the Eskimo. The separation was surprisingly complete, for although the Hudson's Bay Company had occupied trading posts on and near Great Bear lake for more than a century, they had never been able to enter into trade relations with the Eskimo, and did not, in fact, know that there were any Eskimo within reach. These trade relations, by the way, were immediately opened as soon as our work among the Coronation (iulf Eskimo familiarized the traders with the facts of their location and numerical strength.

On the whole our investigations tend to incline us against belief in any great antiquity of the human occupation of the Arctic coast. The evidence is all negative. Nothing that we have seen bears on the face of it any evidence of great age. It seems clear that the Eskimo came into Alaska from the east, and it seems.probable that that event took place not over six hundred years ago at the most.

Mr. Freshfield : We are going to be asked to-night to transfer our interest, which has lately been so deeply and sadly absorbed in the Antarctic, to the Arctic. Mr. Stefansson, who is to lecture to us, is an Icelander by descent, and a citizen of the United States, but was born, I believe, in the Dominion of Canada. At any rate, he has returned to his native allegiance, and the expedition wh'ch he proposes to lear now, for the further exploration of the Arctic regions, is to be under the auspices of the Government of Canada. Mr. Stefansson has already spent more than five years' wandering in the Arctic, very often with no European companion. Perhaps more than any other man living, he has lived with the Eskimo, and studied and made himself master of the lore and traditions of this remote and isolated race. He will, I feel sure, have a great deal of interest to tell to all those of us who are more or less anthropologists-and anthropology and geography are very c'osely united. There have been rumours that he has discovered a tribe of white Eskimo. I do not trust all the news that appears in the newspapers, but no doubt to-night we shall hear what foundation of truth there is for these statements and what are the probable causes of the peculiar features - the difference from other Eskimo-of this particular tribe. As I have already mentioned, the new and very interesting exploration which Mr. Stefansson is about to undertake will be under the auspices of the Government of the Dominion. We owe our thanks to Mr. Borden, the present Premier of Canada, and his colleagues, for the large view they hare taken of the responsibilities of a Government in furthering to the utmost of their power scientific exploration. Long views of this kind seldom lead to loss in the future. There was a time when Mr. Seward, who annexed Alaska to the United States, was told he had made a bad bargain. I do not suppose that there is any. body in the United States who would now repeat that statement. I will not detain you any longer, kut will ask Mr. Stefansson to deliver to us his account of his previous visits to the Arctic and of the Eskimo, and give us some idea of what his proposals for future exploration are.

Dr. A. C. HADDon: It seems superfluous to say how much we have enjoyed this lecture, as it is perfectly obvious we have done so. The point of special interest to me is that of the fair Eskimo to which Mr. Stefansson has alluded. I may remind you that the ordinary Eskimo is a person of short stature, with a large long narrow high head, a very broad face with high cheek-bones, black hair, the hair on the face is very scanty, and a yellow, sometimes brownish-yellow, skin generally 


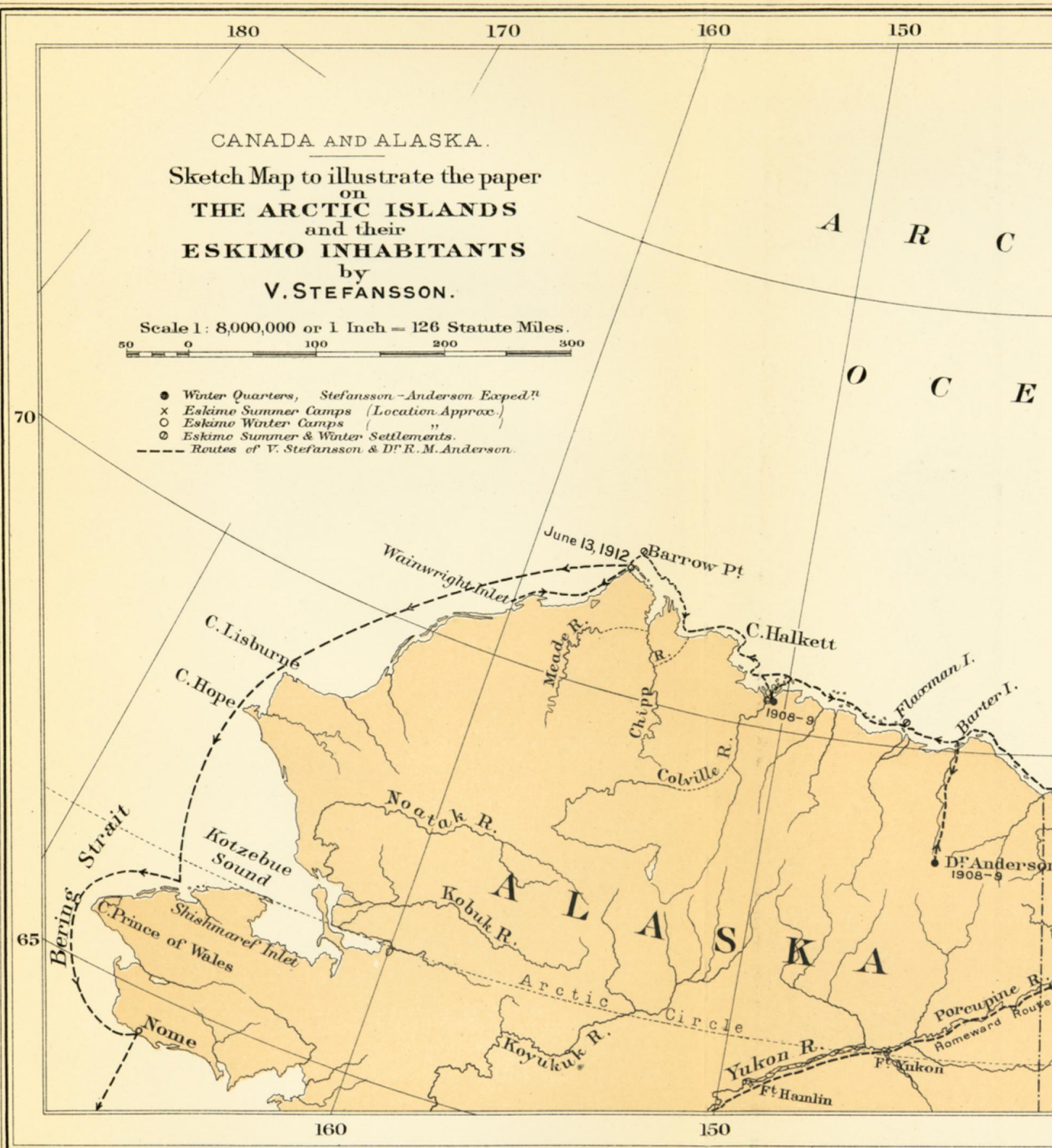

Published by the $R$. 


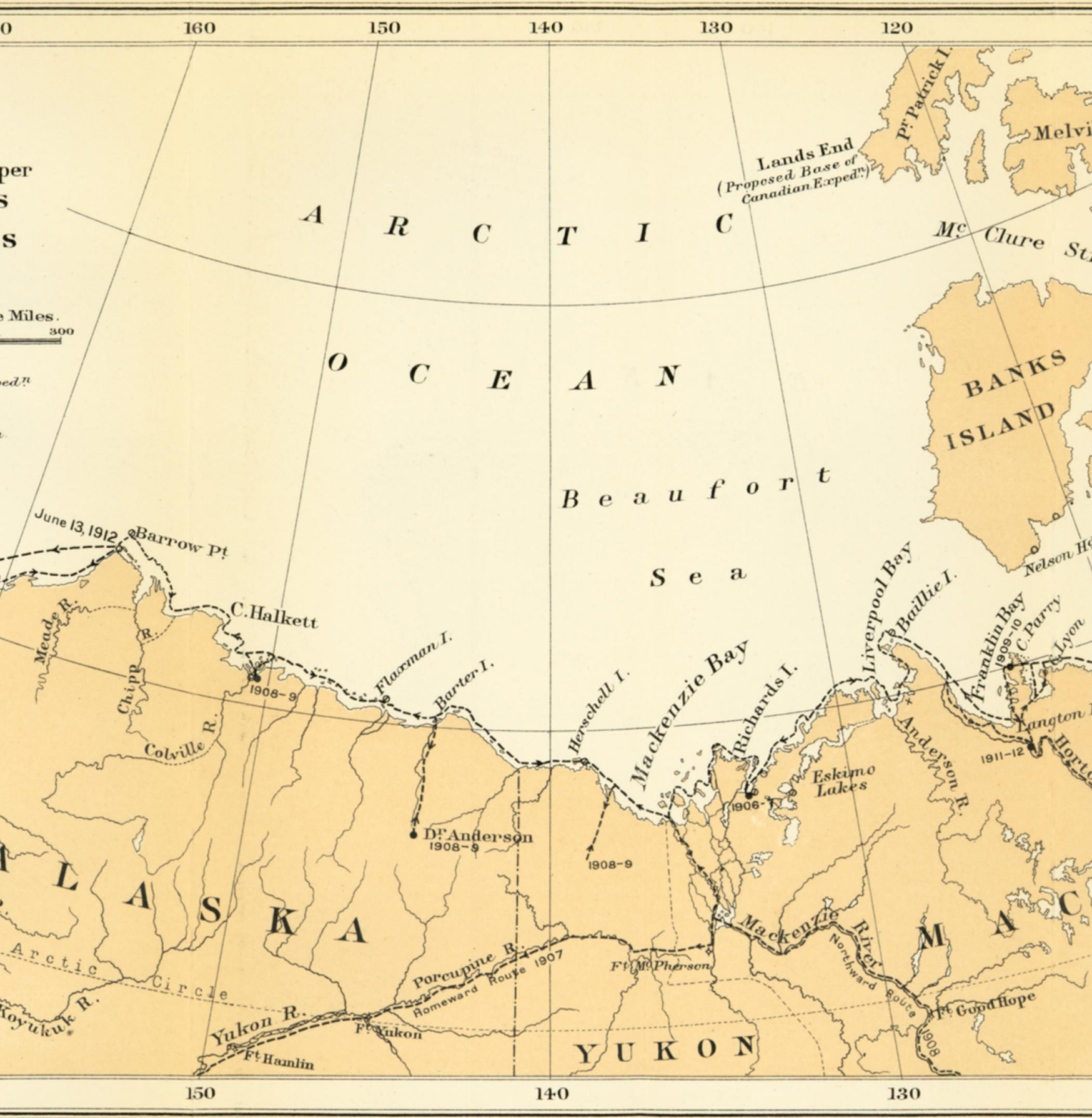

Published by the Royal Geographical Society 


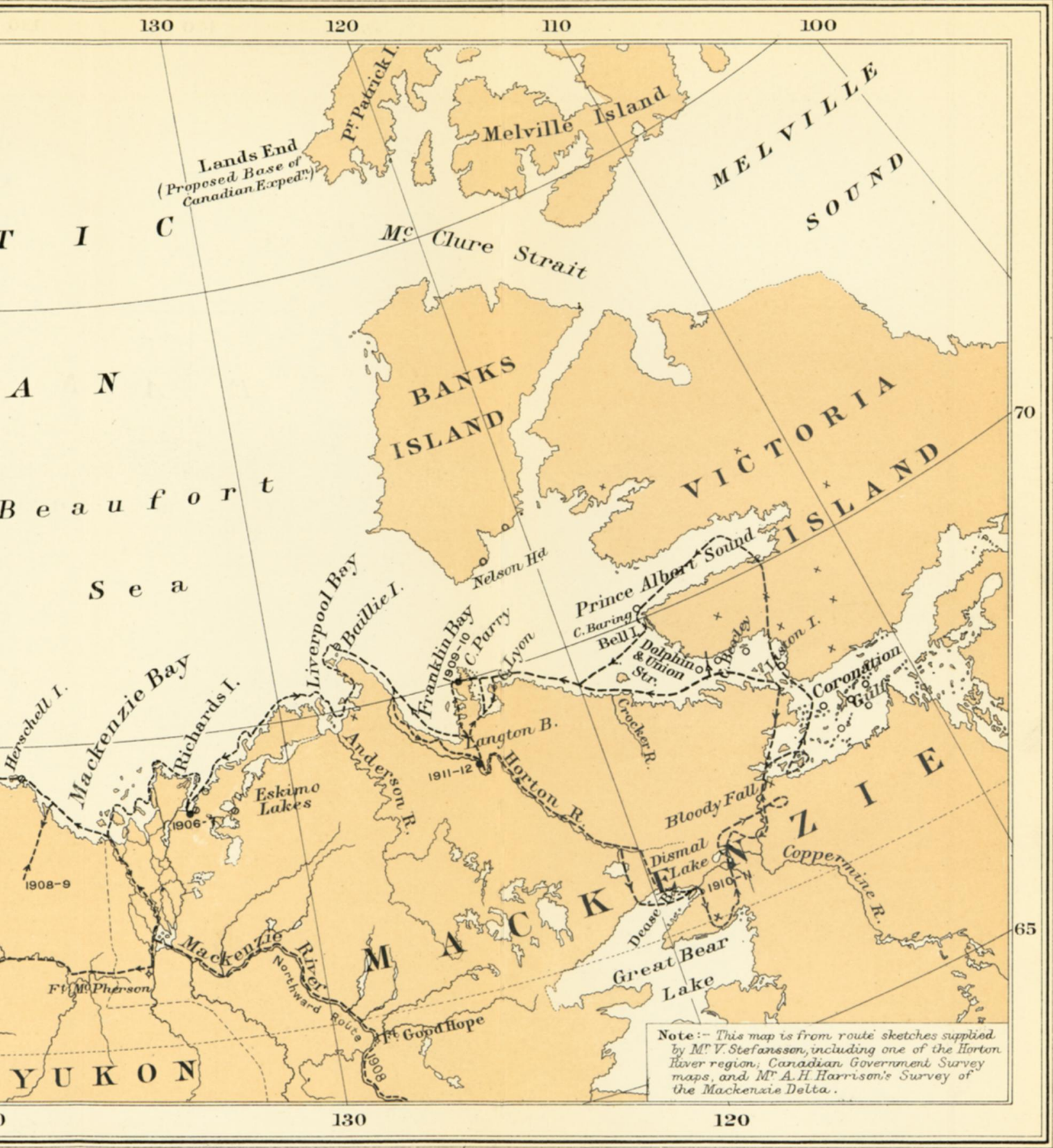

